\title{
Molecular Cloning and Expression Analysis of Cu/Zn SOD Gene from Gynura bicolor DC.
}

\author{
Xin Xu, Zhi-fang Yu, Jing Kong, Mei-jun Yi, Chen Huan, and Li Jiang \\ College of Food Science and Technology, Nanjing Agricultural University, Nanjing 210095, China \\ Correspondence should be addressed to Li Jiang; jiangli@njau.edu.cn
}

Received 29 September 2016; Revised 2 December 2016; Accepted 9 March 2017; Published 18 April 2017

Academic Editor: Alberto Ritieni

Copyright (C) 2017 Xin Xu et al. This is an open access article distributed under the Creative Commons Attribution License, which permits unrestricted use, distribution, and reproduction in any medium, provided the original work is properly cited.

\begin{abstract}
Superoxide dismutase is an important antioxidant enzyme extensively existing in eukaryote, which scavenges reactive oxygen species (ROS) and plays an essential role in stress tolerance of higher plants. A full-length cDNA encoding Cu/Zn SOD was cloned from leaves of Gynura bicolor DC. by rapid amplification of cDNA ends (RACE). The full-length cDNA of Cu/Zn SOD is 924 bp and has a $681 \mathrm{bp}$ open reading frame encoding 227 amino acids. Bioinformatics analysis revealed that belonged to the plant SOD super family. Cu/Zn SODs of the Helianthus annuus, Mikania micrantha, and Solidago canadensis var. scabra all have $86 \%$ similarity to the G. bicolor $\mathrm{Cu} / \mathrm{Zn}$ SOD. Analysis of the expression of $\mathrm{Cu} / \mathrm{Zn}$ SOD under different treatments revealed that $\mathrm{Cu} / \mathrm{Zn} \mathrm{SOD}$ was a stress-responsive gene, especially to 1-MCP. It indicates that the $\mathrm{Cu} / \mathrm{Zn}$ SOD gene would be an important gene in the resistance to stresses and will be helpful in providing evidence for future research on underlying molecular mechanism and choosing proper postharvest treatments for G. bicolor.
\end{abstract}

\section{Introduction}

Reactive oxygen species (ROS) is a group of substances which have oxidation properties to obtain electron from adjacent materials. ROS is classified into two groups in botanical system: inorganic radical, including hydrogen peroxide $\left(\mathrm{H}_{2} \mathrm{O}_{2}\right)$ and singlet oxygen $\left({ }^{1} \mathrm{O}_{2}\right)$, and organic radical, which mainly are the products of membrane lipid peroxidation. The generation and scavenging of ROS are in balance during the plant growth [1]. Nevertheless, the ROS level will be enhanced when plant is exposed to biotic and abiotic stresses, which result in the inactivation of enzymes and breakage of DNA strands and membrane lipids [2,3]. A whole set of mechanisms have been evolved in plant cells to cope with environment stress, scavenge overmuch ROS in time, and adjust internal environment. Scavenging mechanisms include enzymatic and nonenzymatic systems. The former mainly include superoxide dismutase (SOD), ascorbate peroxidase (APX), catalyse (CAT), and glutathione peroxidase (GPX).

Superoxide dismutase (SOD) is an antioxidant enzyme, which plays an important role in process of scavenging ROS through catalyzing the dismutation of superoxide anion to
$\mathrm{H}_{2} \mathrm{O}_{2}$ and molecular oxygen [4]. It is also a sort of important active substances that enhance human health and a kind of important ingredients of functional foods. According to the metal cofactor of catalytic site, SODs are classified into at least three distinct groups: iron SOD (Fe-SOD) in chloroplast, manganese SOD (Mn-SOD) in mitochondrion and peroxisome, and copper/zinc SOD (Cu/ Zn SOD ) in chloroplast and cytosol or in the extra cell which represent $90 \%$ of total SOD. Plant SODs are known to make contribution to defence against toxic oxygen species and are important for stress tolerance consequently. Different types of SODs have their own expression and regulation. The plant SOD gene has been first cloned from corn [5]; then the SOD gene of cassava [6], rice [7], sugarcane [8], and cantaloupe [9] has been cloned and applied to improve the plant resistance in recent years. The cDNA library construction, $5^{\prime}$ - and $3^{\prime}$-rapid amplification of cDNA ends (RACE), and homology cloning are main methods of gene cloning.

Gynura bicolor DC. (G. bicolor) is a perennial plant of the composite Gynura Cass and rich in microelement, anthocyanins [10, 11], amino acid, essential oil [12], and flavonoid $[13,14]$. Its leaves are distinctive reddish-purple in color on the abaxial side, contrasting with typical green 
color on the adaxial side (due to the presence of anthocyanins) [15]. It has potent antioxidant capacity with high SOD activity; therefore it has high nutritional and medicinal value and is beneficial for human health. Since the living organism with high metabolic activity after harvest is prone to losing nutrients and appearance during senescence, proper postharvest treatments are in need for G. bicolor production [16]. Most studies focused on the physiological and biochemical of postharvest treatments, while less gene expression was reported. Therefore we explore effects of 1methylcyclopropene (1-MCP) treatment, nitric oxide (NO) treatment, controlled atmosphere treatment, and hypobaric treatment to G. bicolor at the molecular level.

We herein described the molecular cloning and characterization of $\mathrm{Cu} / \mathrm{Zn}$ SOD gene from G. bicolor. The bioinformatics analysis and expression of $\mathrm{Cu} / \mathrm{Zn}$ SOD under different treatments were also studied, which will be helpful in providing evidence for future research on underlying molecular mechanism and improving yields of postharvest treatments of G. bicolor and other leafy vegetables.

\section{Materials and Methods}

2.1. Plant Materials and Treatments. G. bicolor leaves were obtained from a commercial farmland in Shanghai, China. Harvested leaves were precooled to $2-5^{\circ} \mathrm{C}$ and delivered to the laboratory immediately. Then the leaves without visual defects (pest-damaged, bruised, and defective) were randomly divided into six groups and subjected to the following treatments: (1) Being stored in room temperature: (a) control group (CK): without any treatment; (b) 1-MCP treatment (MT): leaves were closed up in desiccators in the presence of $50 \mu \mathrm{L} / \mathrm{L}$ 1-MCP (Agrofresh, USA) for $6 \mathrm{~h}$. KOH (Sinopharm Chemical Reagent Beijing Co., Ltd., China) solution (1\% $(\mathrm{w} / \mathrm{v}))$ was placed inside it to absorb $\mathrm{CO}_{2}$ during treatment; (c) nitric oxide (NO) treatment (NT): $10 \mu \mathrm{L} / \mathrm{L}$ nitric oxide (Source Gas Co., Ltd., Nanjing, China) was injected into desiccators; then leaves were closed up in it for $3 \mathrm{~h}$. Then these groups were stored in a room held at $20-25^{\circ} \mathrm{C}$ for 7 days; leaves from each treatment group were frozen in liquid nitrogen and stored at $-80^{\circ} \mathrm{C}$ on days $0,1,3,5$, and 7. (2) Being stored in low temperature: (d) control group (CKL): without any treatment; (e) controlled atmosphere treatment (CA): leaves were placed in normal polyethylene plastic bags with a controlled atmosphere of $3 \% \mathrm{O}_{2}$ and $97 \% \mathrm{~N}_{2}$ (controlled $\mathrm{CO}_{2}<1 \%$ ); the gas compositions were continuously controlled constant throughout the storage; (f) hypobaric treatment $(\mathrm{HT})$ : leaves were put in a plastic basket and placed into a hypobaric chamber, whose pressure was $61.33 \mathrm{kPa}$. These groups were treated at $4^{\circ} \mathrm{C}$ for 20 days; leaves from each treatment group were frozen in liquid nitrogen and stored at $-80^{\circ} \mathrm{C}$ on days $0,5,10,15$, and 20 .

2.2. RNA Extraction. The G. bicolor leaves were pulverized with liquid nitrogen firstly; then total RNA was isolated from the leaves using a modified CTAB method. The total RNA concentration and purity were measured by microultraviolet spectrophotometer (Thermo Electron, America), and RNA integrity was checked by agarose gel electrophoresis.
2.3. Conserved Sequence of Cu/Zn SOD cDNA Amplifying. The first strand cDNA was synthesized using PrimeScript RT reagent Kit (TaKaRa, Japan). The degenerate primers $(\mathrm{Cu} / \mathrm{Zn}$ SOD-F: $5^{\prime}$-GGRTTCCATGTYCAYGCYCTTGG- ${ }^{\prime}$ and Cu/ Zn SOD-R: $5^{\prime}$-CATGHCCNCCCCTBCCAAGATCATC- ${ }^{\prime}$ ) were designed based on the homology to the $\mathrm{Cu} / \mathrm{Zn}$ SOD genes from Solidago canadensis (O04996.3), Mikania micrantha (ACZ51444.1), Helianthus annuus (CAH06454.1), and Ipomoea batatas (AFY26880.1).

PCR was conducted using the following procedure: the template was denatured at $95^{\circ} \mathrm{C}$ for $5 \mathrm{~min}$ followed by 30 cycles at $94^{\circ} \mathrm{C}$ for $1 \mathrm{~min}, 60^{\circ} \mathrm{C}$ for $40 \mathrm{~s}$, and $72^{\circ} \mathrm{C}$ for $1 \mathrm{~min}$ and extended for $10 \mathrm{~min}$ at $72^{\circ} \mathrm{C}$. Amplicons of expected sizes were recovered from the agarose gel and purified using AxyPrep ${ }^{\mathrm{TM}}$ DNA Gel Extraction Kit (Axygen, America), then subcloned into the pMD 19-T cloning vector (TaKaRa, Japan), and transformed into competent Escherichia coli DH5 $\alpha$ cells (Trans, China). The bacterium solution as template performed PCR using the same procedure as that above, and the positive clones were sequenced in Nanjing GenScript Biological Technology Co., Ltd. (Nanjing, China).

2.4. Molecular Cloning of the Full-Length Cu/Zn SOD cDNA by RACE. The $3^{\prime}$ - and $5^{\prime}$-ends of the G. bicolor $\mathrm{Cu} / \mathrm{Zn}$ SOD cDNA were PCR-amplified using SMARTer RACE $5^{\prime} / 3^{\prime} \mathrm{Kit}$ (TaKaRa, Japan). A total of four gene-specific primers ( $3^{\prime} \mathrm{R}-1: 5^{\prime}$-CGATCTTGGGAATGTCACAGTAGGC- $3^{\prime} ; 3^{\prime} \mathrm{R}-$ 2: $5^{\prime}$-TGGGAATGTCACAGTAGGCGAAGA-3'; $5^{\prime} \mathrm{R}-1: 5^{\prime}$ ACATTCCCAAGATCGCCAGCAT- $3^{\prime}$; and $5^{\prime} \mathrm{R}-2$ : $5^{\prime}$-CCATCTTCGCCTACTGTGACATTCC- $3^{\prime}$ ) were designed based on the sequence of the internal conservative fragment. PCR amplification programs for both the $3^{\prime}$ and $5^{\prime}$ RACE were as follows: 5 cycles at $94^{\circ} \mathrm{C}$ for $30 \mathrm{~s}, 72^{\circ} \mathrm{C}$ for $3 \mathrm{~min} ; 5$ cycles at $94^{\circ} \mathrm{C}$ for $30 \mathrm{~s}, 70^{\circ} \mathrm{C}$ for $30 \mathrm{~s}$, and $72^{\circ} \mathrm{C}$ for $3 \mathrm{~min}$; and 25 cycles at $94^{\circ} \mathrm{C}$ for $30 \mathrm{~s}, 68^{\circ} \mathrm{C}$ for $30 \mathrm{~s}$, and $72^{\circ} \mathrm{C}$ for $3 \mathrm{~min}$. Amplicons of RACE-PCR were subsequently cloned and sequenced as 2.3 .

2.5. Bioinformatics Analysis. The nucleotide sequence, deduced amino acid sequence, and open reading frame (ORF) of $\mathrm{Cu} / \mathrm{Zn}$ SOD cDNA were analyzed using the software Vector NTI Advance 11.5.1. Homology search was carried out and $\mathrm{Cu} / \mathrm{Zn} \mathrm{SOD}$ sequences from different organisms were obtained using the NCBI BLAST search program. MEGA6 software was used for phylogenetic analysis with neighbourjoining method.

Protein analyses of physicochemical properties were performed using ProtParam and ProtScal program of ExPASy tools. Signal peptide, transmembrane domain, subcellular localization, and conserved domain were predicted by the Signal P 4.1, TMHMM, ProtComp Version 9.0, and Batch $\mathrm{CD}$-search program, respectively. The secondary structure was predicted by SOPMA program and the presumed tertiary structure was established using the SWISS-MODEL workspace.

2.6. Expression Analysis by Quantitative RT-PCR. mRNA relative expression of $\mathrm{Cu} / \mathrm{Zn}$ SOD in $G$. bicolor was analyzed by the method of real-time quantitative RT-PCR with a 


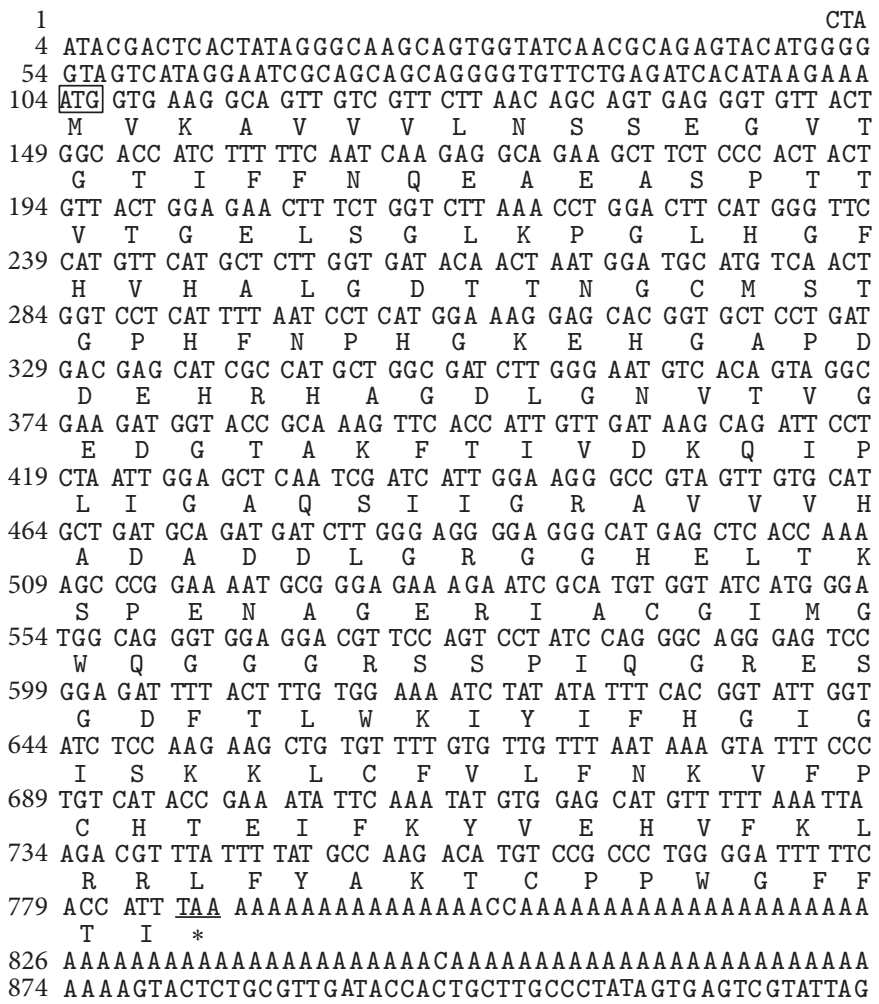

FIGURE 1: The full-length cDNA sequence and deduced amino acid sequence of G. bicolor Cu/Zn SOD. The start codon (ATG) is boxed and the stop codon (TAA) is underlined.

Bio-Rad CFX96 Real-Time System (C1000 Thermal Cycler) (Bio-Rad, USA). RNA treated with $50 \mu \mathrm{L} / \mathrm{L} 1-\mathrm{MCP}$ and $10 \mu \mathrm{L} / \mathrm{L}$ nitric oxide, controlled atmosphere $\left(3 \% \mathrm{O}_{2}\right.$ and $\left.97 \% \mathrm{~N}_{2}\right)$, and hypobaric $(61.33 \mathrm{kPa})$ were extracted. Total RNA was reverse-transcribed into cDNA using PrimeScript RT reagent Kit with gDNA Eraser (TaKaRa, Japan). The PCR reaction was performed in $20 \mu \mathrm{L}$ volume containing $10 \mu \mathrm{L}$ SYBR premix Ex Taq, $0.8 \mu \mathrm{L}$ each primer solution, and $1 \mu \mathrm{L}$ cDNA solution as a template, and then RNase-free water was added to a total $20 \mu \mathrm{L}$ volume. The specific qRT-PCR primers were $\mathrm{Cu} / \mathrm{Zn}$ SOD-real-F (5' ACCGCAAAGTTCACCATTGTTGATAAG-3 ${ }^{\prime}$ ) and $\mathrm{Cu} / \mathrm{Zn}$ SOD-R ( $5^{\prime}$-TGCCCTGGATAGGACTGGAACG- $\left.3^{\prime}\right)$, and the primers of internal control were Actin-real-F ( $5^{\prime}$-AGGAATGGTGAAGGCAGGGTTTG-3') and Actin-real-R (5' -TTGTCCCATACCAACCATAACACCAG- $\left.3^{\prime}\right)$. The amplification was performed by the following procedure: initial denaturation at $95^{\circ} \mathrm{C}$ for $30 \mathrm{~s}$ followed by 40 cycles of amplification $\left(95^{\circ} \mathrm{C}\right.$ for $5 \mathrm{~s}$ and $60^{\circ} \mathrm{C}$ for $\left.30 \mathrm{~s}\right)$. Samples were normalized with Actin, and the relative expression levels were calculated using the $2^{-\Delta \Delta \mathrm{Ct}}$ method. Each assay was repeated in triplicate.

2.7. Statistical Analysis. All data of expression analysis were average values of three replicates with standard errors (SE). Standard errors (SE) were calculated by Microsoft Excel and the figures revealed differences between experimental treatments that were performed with the SPSS 20.0 software (SPSS Inc., Chicago, IL, USA). The data were treated by analysis of variance using Duncan's test. A 95\% confidence level $(p<0.05)$ was used for all analyses.

\section{Results and Discussion}

3.1. Sequence of G. bicolor $\mathrm{Cu} / \mathrm{Zn}$ SOD cDNA. The full-length cDNA of $G$. bicolor $\mathrm{Cu} / \mathrm{Zn}$ SOD was deduced by aligning and assembling the $3^{\prime}$-end, $5^{\prime}$-end, and conserved sequences. The full-length sequence of cDNA consists of 924 bp nucleotides, and it contains $103 \mathrm{bp}$ in the $5^{\prime}$ untranslated region, an open reading frame (ORF) of $681 \mathrm{bp}$ at position $104-784 \mathrm{bp}$, encoding a deduced protein of 227 amino acid residues, and $140 \mathrm{bp}$ in the $3^{\prime}$ untranslated region (Figure 1).

3.2. Multiple Alignment and Phylogenetic Analysis of $G$. bicolor $\mathrm{Cu} / \mathrm{Zn} S O D$. The alignment analysis by Blast search in NCBI database revealed that $G$. bicolor $\mathrm{Cu} / \mathrm{Zn}$ SOD shared high homology with many other $\mathrm{Cu} / \mathrm{Zn}$ SODs, such as Helianthus annuus $\mathrm{Cu} / \mathrm{Zn}$ SOD (CAH06454.1), Mikania micrantha $\mathrm{Cu} / \mathrm{Zn}$ SOD (ACZ51444.1), and Solidago canadensis var. scabra $\mathrm{Cu} / \mathrm{Zn}$ SOD (O04996.3) have $86 \%$ identity to G. bicolor $\mathrm{Cu} / \mathrm{Zn} \mathrm{SOD}$, which hints the high conservation of $\mathrm{Cu} / \mathrm{Zn}$ SODs during the long period of evolution. Multiple sequence alignment of 12 amino acid sequences which have high identity to $G$. bicolor $\mathrm{Cu} / \mathrm{Zn}$ SOD finds many high conserved domains; therefore the amplified sequence is a typical $\mathrm{Cu} / \mathrm{Zn}$ SOD sequence (Figure 2).

With the MEGA6 program, a neighbour-joining (NJ) tree was constructed based on the deduced amino acid sequence 


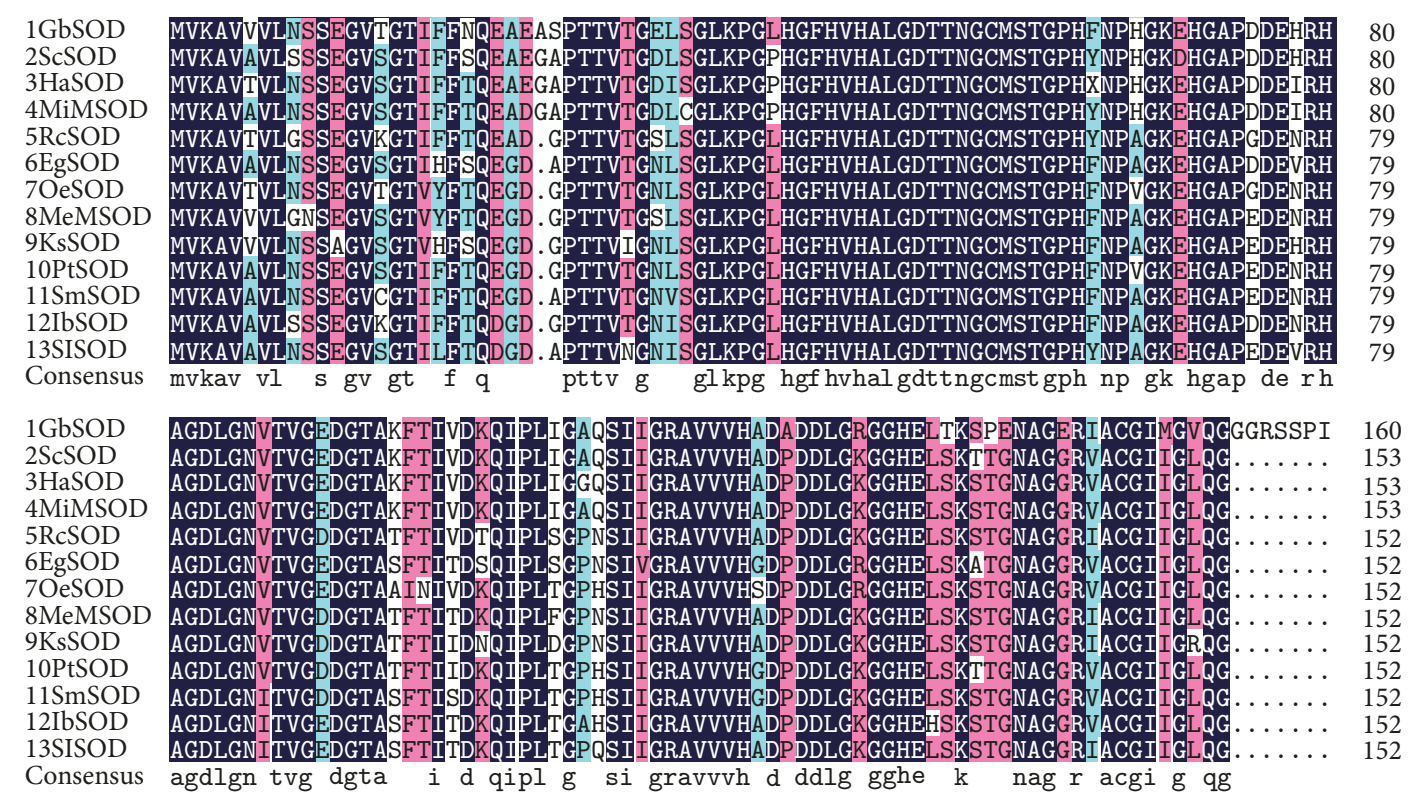

Figure 2: Multiple alignment with other plant species: (1) G. bicolor; (2) Solidago canadensis (gi|3914998|sp|O04996.3|); (3) Helianthus annuus (gi|50978416|emb|CAH06454.1|); (4) Mikania micrantha (gi|269856434|gb|ACZ51444.1|); (5) Ricinus communis (gi|255542450| ref|XP_002512288.1|); (6) Erythranthe guttata (gi|848852837|ref|XP_012841088.1|); (7) Olea europaea (gi|160962549|gb|ABX54845.1|); (8) Melastoma malabathricum (gi|295979335|dbj|BAJ07302.1|); (9) Knorringia sibirica (gi|259016718|gb|ACV89347.1|); (10) Populus trichocarpa (gi|566169463|ref|XP_006382702.1|); (11) Salix matsudana (gi|747192169|gb|AJE26130.1|); (12) Ipomoea batatas (gi|427199298| gb|AFY26880.1|); (13) Solanum lycopersicum (gi|902763183|ref|NP_001234031.2|).

of $\mathrm{G}$. bicolor $\mathrm{Cu} / \mathrm{Zn} \mathrm{SOD}$ and other plant $\mathrm{Cu} / \mathrm{Zn}$ SODs to investigate the evolutionary relationships. The result reveals that $\mathrm{G}$. bicolor $\mathrm{Cu} / \mathrm{Zn} \mathrm{SOD}$ has the same evolutionary origin with other analyzed plants. G. bicolor and Compositae plant such as Helianthus annuus, Mikania micrantha, and Solidago canadensis are a cluster and share a close relationship with Salicaceae and Solanaceae plant. Thus it can be seen that $\mathrm{Cu} / \mathrm{Zn} \mathrm{SOD}$ has a certain genus characteristic in phylogenetic relationships (Figure 3).

\subsection{Molecular Characteristics of Deduced G. bicolor $\mathrm{Cu} / \mathrm{Zn}$ SOD Amino Acid Sequence}

3.3.1. The Primary Structure Analysis. The results of physicochemical properties with ProtParam program of ExPASy are as follows. The calculated molecular mass is $24.52 \mathrm{kDa}$, and the theoretical isoelectric point ( $\mathrm{pI}$ ) is 6.66. The polypeptide consists of 20 types of amino acid, the highest content of it is Gly $(13.7 \%)$, acidic amino acid (D, E) is $10.1 \%$, basic amino acid $(\mathrm{K}, \mathrm{R})$ is $9.2 \%$, hydrophobic amino acid $(\mathrm{A}, \mathrm{I}, \mathrm{L}, \mathrm{F}, \mathrm{W}$, and $\mathrm{V})$ is $34.4 \%$, polar amino acid $(\mathrm{N}, \mathrm{C}, \mathrm{Q}, \mathrm{S}, \mathrm{T}$, and $\mathrm{Y})$ is $20.6 \%$, and charged residue $(\mathrm{R}, \mathrm{K}, \mathrm{H}, \mathrm{Y}, \mathrm{C}, \mathrm{D}$, and $\mathrm{E})$ is $28.5 \%$. The instability index is computed to be 28.40 ; this classifies the protein as stable (index $<40$ ). Grand average of hydropathicity (GRAVY) is -0.132 , classified as hydrophilia protein (hydrophobic protein: $0<$ GRAVY $<2$; hydrophilia protein: $-2<$ GRAVY $<0$ ), the analysis of hydropathy profile using ProtScal program of ExPASy has the same result, and most of amino acid residues have stronger hydrophilicity, whereas $\mathrm{N}$-end and $\mathrm{C}$-end regions have hydrophobicity.
Predicted by the Signal P 4.1 program, result indicates that $\mathrm{N}$-end of the deduced protein has no signal peptide, classified as nonsecretory protein. Analyzed by the TMHMM server, result shows that the protein is located in the outside of membrane and has no transmembrane domain; therefore the protein can be deduced in cytoplasmic matrix. Based on the predicted subcellular localization, it is most probably located in the cytoplasm with prediction value of 3.8. In summary, the protein belongs to nonsecretory protein located in cytoplasmic matrix.

Furthermore, there are four amino acid residues (His-46, His-48, His-63, and His-120) and four amino acid residues (His-63, His-71, His-80, and Asp-83) binding to copper and zinc, respectively, analyzed by Batch $\mathrm{CD}$-search program.

3.3.2. Secondary Structure. Protein secondary structure prediction analyzed by SOPMA program indicates that the protein contains $\alpha$-helix (h), extended strand (e), $\beta$-turn (t), and random coil (c), which accounted for $12.78 \%, 29.96 \%$, $11.45 \%$, and $45.81 \%$ of total amino acids, respectively. On the whole structure, random coil and extended strand are the main structural element, and $\alpha$-helix and $\beta$-turn are distributed in the protein.

3.3.3. Tertiary Structure. According to the prediction method of homology modeling, the potential tertiary structure of the $\mathrm{Cu} / \mathrm{Zn}$ SOD from $G$. bicolor was established using the SWISSMODEL workspace, based on the A-chain model of $\mathrm{Cu} / \mathrm{Zn}$ SOD from Potentilla atrosanguinea (PDB code: 2Q2L) with identity of $80.26 \%$ (Figure 4 ). The tertiary structure showed 


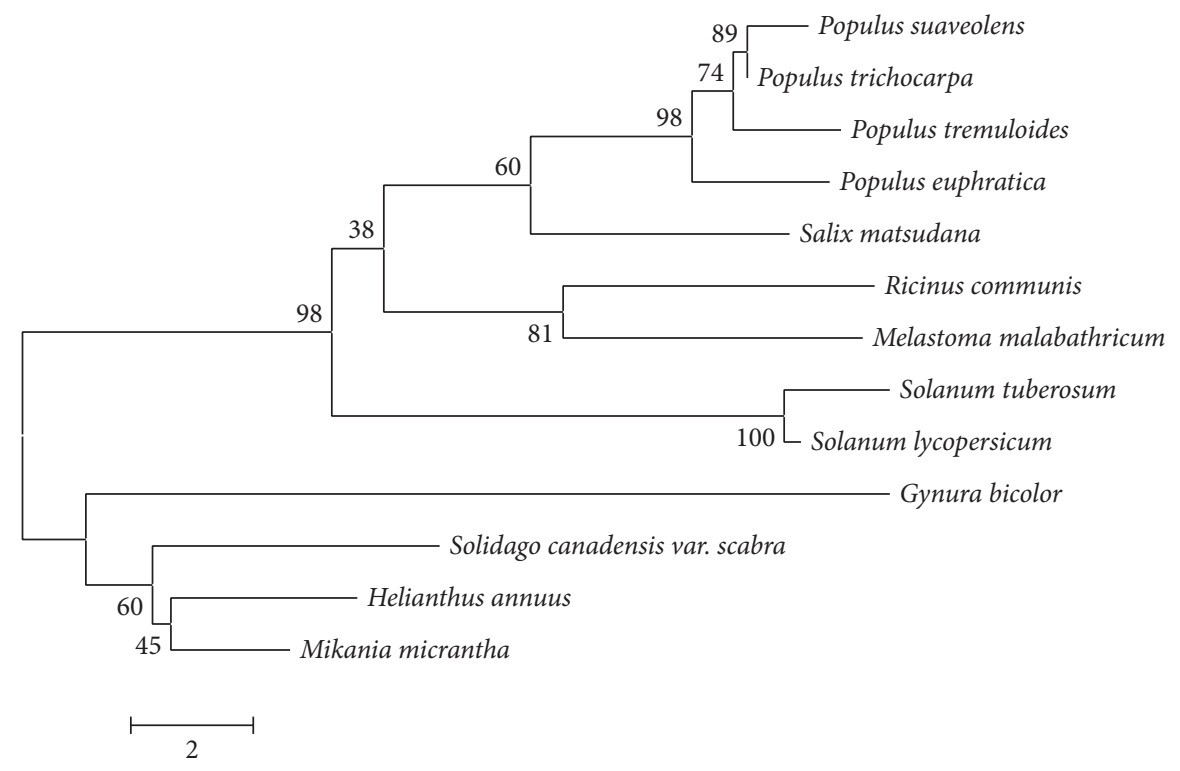

FIGURE 3: Phylogenic analysis with other plants.

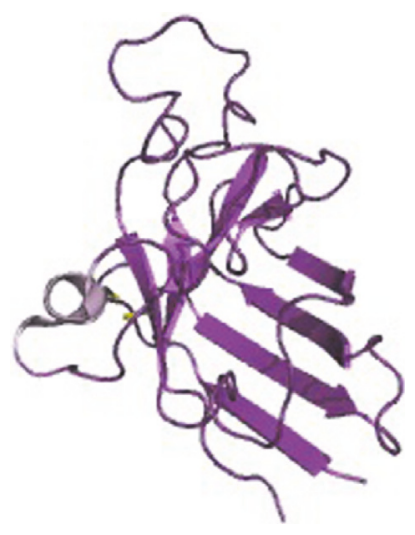

FIGURE 4: Prediction of protein tertiary structure of G. bicolor $\mathrm{Cu} / \mathrm{Zn}$ SOD (the tertiary structure based on the A-chain model of $\mathrm{Cu} / \mathrm{Zn}$ SOD from Potentilla atrosanguinea (PDB code: $2 \mathrm{Q} 2 \mathrm{~L}$ ) showed that the $\mathrm{Cu} / \mathrm{Zn}$ SOD contained eight antiparallel $\beta$-strands forming a flattened cylinder).

that the $\mathrm{Cu} / \mathrm{Zn}$ SOD contained a novel eight antiparallel $\beta$ strands forming a flattened cylinder, which was similar to the $\mathrm{Cu} / \mathrm{Zn}$ SOD in Brassica campestris [17]. Ramachandran plot generated by Procheck shows that amino acids of the predicted model in most favoured regions, additional allowed regions, and generously allowed regions are $89.3 \%, 9.9 \%$, and $0.8 \%$, respectively, which reveals that structure of the predicted model has good stability. Overall average of GFactors is -0.22 , which shows that the structure belongs to the ordinary range.

3.4. Expression Analysis of $\mathrm{Cu} / \mathrm{Zn} \mathrm{SOD}$ Gene under Different Treatments. The expression of $\mathrm{Cu} / \mathrm{Zn}$ SOD gene under different treatments including 1-MCP, NO, controlled atmosphere, and hypobaric pressure in G. bicolor was performed by realtime RT-PCR. The results showed that the four treatments caused the upregulation of $\mathrm{Cu} / \mathrm{Zn}$ SOD gene with different degree (Figures 5 and 6).

After 1-MCP treatment the expression of $\mathrm{Cu} / \mathrm{Zn}$ SOD gene was elevated to 18.58 -fold at peak time point $1 \mathrm{~d}$ and then declined and decreased to 1.1 times at $7 \mathrm{~d}$. The same variation trend was observed in the SOD activity of G. bicolor [18]: G. bicolor was treated in the presence of $0.25 \mathrm{ppm}, 0.50 \mathrm{ppm}$, and $1.00 \mathrm{ppm} \mathrm{1-MCP} \mathrm{for} 6 \mathrm{~h}, 12 \mathrm{~h}$, and $24 \mathrm{~h}$ respectively, and then stored in $0 \pm 1^{\circ} \mathrm{C}$. The results showed that the SOD activity level first increased and then decreased slowly and peaked at $5 \mathrm{~d}$. The SOD activity of Brassica oleracea [19], Ficus carica [20], and kiwifruit [21] also had the same variation trend. So we can deduce that, in the earlier storage of some leafy vegetables and fruits, $1-\mathrm{MCP}$ treatment can induce the expression of $\mathrm{Cu} / \mathrm{Zn} \mathrm{SOD}$ gene and then upregulated the activity level

In NO treatment, the expression level increased continuously with a slight reduction at $5 \mathrm{~d}$ and peaked at $7 \mathrm{~d}$ (2.89fold). The variation trend was similar to the SOD activity of rape [22]. While the variation trend of SOD activity and gene expression was different in banana [23], the activity of SOD in NO treatment increased gradually, reaching a maximum at day 3. Thereafter, a decline occurred with a slight increase at day 9. The expression levels are consistent with the changes of SOD activity. So we deduced that the induction mechanism of NO treatment in vegetables was perhaps different in fruits.

Under hypobaric treatment the expression pattern has similar variation trend to $1-\mathrm{MCP}$; the highest level was achieved at $10 \mathrm{~d}$, which was 2.71 times, and then declined, which was consistent with the SOD activity of blueberry [24] and tomato [25].

The expression of $\mathrm{Cu} / \mathrm{Zn}$ SOD gene in controlled atmosphere treatment has two peaks, 3.43 times at $5 \mathrm{~d}$ and 2.65 


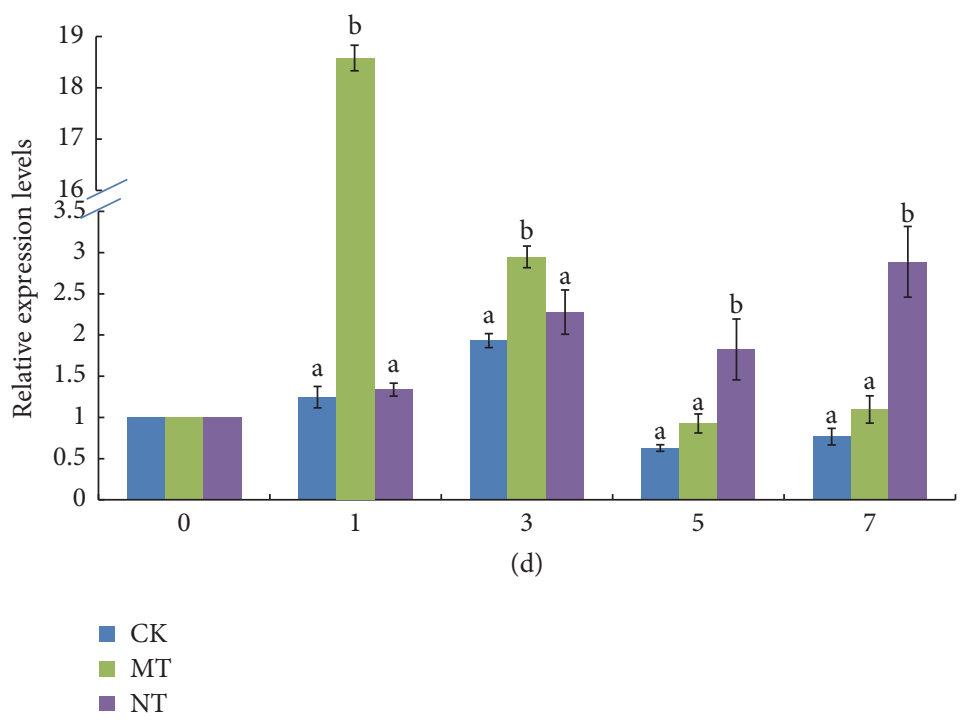

FIGURE 5: Expression profile by qRT-PCR with 1-MCP and NO treatments (CK: control group; MT: 1-MCP treatment; NT: nitric oxide (NO) treatment). ( $\mathrm{a}$ and $\mathrm{b})$ Differences between experimental treatments that were performed with the SPSS 20.0 software.

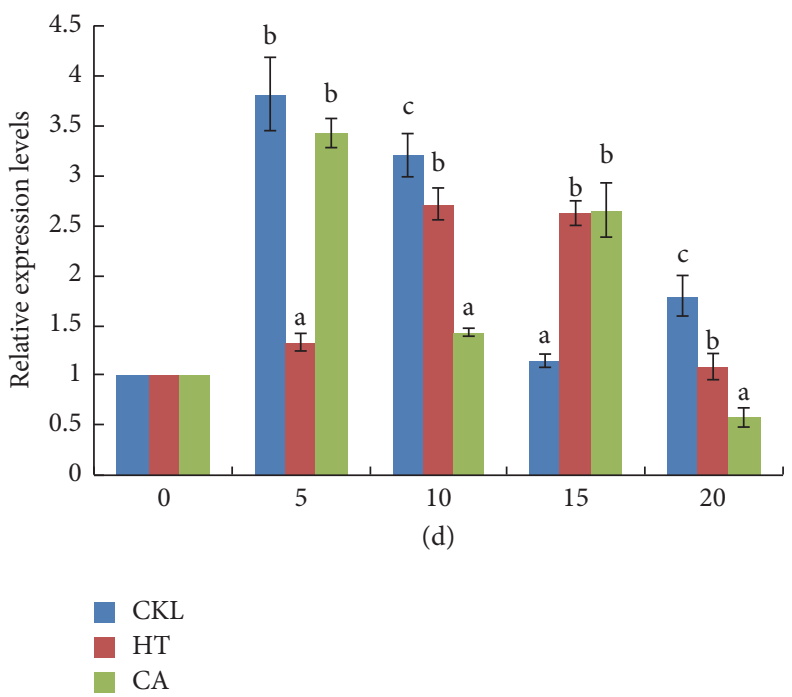

FIGURE 6: Expression profile by qRT-PCR with controlled atmosphere and hypobaric treatments (CKL: control group; CA: controlled atmosphere treatment; HT: hypobaric treatment). (a, b, and c) Differences between experimental treatments that were performed with the SPSS 20.0 software.

times at $15 \mathrm{~d}$, respectively, while the SOD activity of G. bicolor first decreased and then increased, reaching a maximum at day 15 and thereafter a slight decline at day 20 [18]. So we speculated that, in this treatment, other factors participated in the induction of expression of $\mathrm{Cu} / \mathrm{Zn}$ SOD gene, and regulation of gene to activity was time-lapse.

In this study, we also found that a low temperature could affect the expression of $\mathrm{Cu} / \mathrm{Zn} \mathrm{SOD}$ gene, and the expression level of CKL group was elevated (3.82-fold) at $5 \mathrm{~d}$, while the expression of CK group decreased (0.63-fold) at the same time. So we speculated that a low temperature could induce expression of $\mathrm{Cu} / \mathrm{Zn} \mathrm{SOD}$ gene.

The results suggested that the four treatments were effective for induction of expression of $\mathrm{Cu} / \mathrm{Zn} \mathrm{SOD}$ gene, and
1-MCP treatment was the most obvious. Different expression patterns of treatments result from different regulatory mechanism. The expression amount of 1-MCP, controlled atmosphere, and hypobaric treatments dropped to the level comparable to the original level at the last time point. It was indicated that the influence of the three treatments on the expression of $\mathrm{Cu} / \mathrm{Zn} \mathrm{SOD}$ gene was time-controlled. In the group stored at $4^{\circ} \mathrm{C}$, the expression amount of controlled atmosphere and hypobaric treatments was less than control group in the same time point before $15 \mathrm{~d}$ and more than at $15 \mathrm{~d}$, because low oxygen concentration and low pressure can inhibit accumulation of superoxide anion [26-28]; therefore the expression of $\mathrm{Cu} / \mathrm{Zn}$ SOD gene reduced before $15 \mathrm{~d}$, and inhibiting effect was not obvious at $15 \mathrm{~d}$. 


\section{Conclusions}

A full-length cDNA of $\mathrm{Cu} / \mathrm{Zn}$ SOD from leaves of $G$. bicolor was isolated and characterized in this paper. Multiple alignments and bioinformatics analysis results indicated that the deduced $\mathrm{Cu} / \mathrm{Zn}$ SOD had high similarity to other plant $\mathrm{Cu} / \mathrm{Zn}$ SODs, which further proves the cloned gene is $\mathrm{Cu} / \mathrm{Zn}$ SOD gene. The result supported the hypothesis that $\mathrm{Cu} / \mathrm{Zn}$ SOD may play an important role in bioprocess and thus are conserved in evolution. Expression profiles of $\mathrm{Cu} / \mathrm{Zn}$ SOD under different treatments suggest that $\mathrm{Cu} / \mathrm{Zn} \mathrm{SOD}$ was a stress-responsive gene, especially to 1-MCP. The molecular cloning, characterization, and expression analysis of $\mathrm{Cu} / \mathrm{Zn}$ SOD will be helpful to choose proper postharvest treatments for $G$. bicolor and other leafy vegetables.

\section{Conflicts of Interest}

The authors declare that there are no conflicts of interest regarding the publication of this paper.

\section{Acknowledgments}

This work was supported by the National Natural Science Foundation of China (no. 31301576) and Special Fund for Agro-Scientific Research in the Public Interest (no. 2014030232).

\section{References}

[1] R. G. Alscher, N. Erturk, and L. S. Heath, "Role of superoxide dismutases (SODs) in controlling oxidative stress in plants," Journal of Experimental Botany, vol. 53, no. 372, pp. 1331-1341, 2002.

[2] G. H. Wu, R. W. Wilen, A. J. Robertson, and L. V. Gusta, "Isolation, chromosomal localization, and differential expression of mitochondrial manganese superoxide dismutase and chloroplastic copper/zinc superoxide dismutase genes in wheat," Plant Physiology, vol. 120, no. 2, pp. 513-520, 1999.

[3] K. Apel and H. Hirt, "Reactive oxygen species: metabolism, oxidative stress, and signal transduction," Annual Review of Plant Biology, vol. 55, pp. 373-399, 2004.

[4] D. D. Mruk, B. Silvestrini, M.-Y. Mo, and C. Y. Cheng, "Antioxidant superoxide dismutase-a review: its function, regulation in the testis, and role in male fertility," Contraception, vol. 65, no. 4, pp. 305-311, 2002.

[5] R. E. Cannon, J. A. White, and J. G. Scandalios, "Cloning of cDNA for maize superoxide dismutase-2(SOD2)," Proceedings of the National Academy of Sciences of the United States of America, vol. 84, no. 1, pp. 179-183, 1987.

[6] H.-S. Lee, K.-Y. Kim, S.-H. You, S.-Y. Kwon, and S.-S. Kwak, "Molecular characterization and expression of a cDNA encoding copper/zinc superoxide dismutase from cultured cells of cassava (Manihot esculenta Crantz)," Molecular and General Genetics, vol. 262, no. 4-5, pp. 807-814, 1999.

[7] F. Wang, H. B. Wang, and J. F. Wang, "Sequence and expression analysis of cytoplasmic copper/zinc superoxide dismutase gene in rice," Journal of Tropical and Subtropical Botany, no. 2, pp. 101-106, 2007.
[8] S. Wang, B. Q. Zhang, X. Huang, Y. J. Fan, L. T. Yang, and Y. R. Li, "Molecular cloning of sugarcane $\mathrm{Cu} / \mathrm{Zn}$ superoxide dismutase (Cu/Zn-SOD) and its expression analysis," Scientia Agricultura Sinica, vol. 46, no. 15, pp. 3277-3284, 2013.

[9] W. R. Ma, C. H. Shan, J. M. Tong, and T. Liu, "Cloning and bioinformatics analysis of $\mathrm{Cu} / \mathrm{Zn}$-SOD gene from cantaloupe," Science and Technology of Food Industry, vol. 35, no. 13, pp. 181185, 2014.

[10] Q. X. Lin, L. Hu, L. L. Gong, and L. Y. Chen, "The stability of extract from Begonia fimbristipula Hance's pigment and optimization of its processing parameters," Chinese Agricultural Science Bulletin, vol. 20, no. 1, pp. 141-143, 2004.

[11] S. P. Zhang, S. L. Qiu, Y. Deng et al., "Study and application of the anthocyanin from Gynum bicolor," Chinese Agricultural Science Bulletin, vol. 31, no. 22, pp. 157-162, 2015.

[12] Q. Lv, J. Qin, and T. Chen, "Study on essential oil components in stem and leaf of Gynura Bicolor DC," Journal of Guizhou University of Technology, vol. 33, no. 2, pp. 23-25, 2004.

[13] L. H. Zhang, C. Y. Tu, W. T. Yu, and H. L. Wu, "Analysis of nutritive components and flavones in Gynura," Amino Acids and Biotic Resources, vol. 26, no. 3, pp. 3-5, 2004.

[14] K. M. Luo, G. G. Zhang, F. Chen, and Y. Q. Huang, "Antioxidant activity of the flavonoids of Gynura in vitro and in vivo," Fine Chemicals, vol. 29, no. 10, pp. 937-941, 2012.

[15] Y. Shimizu, T. Imada, H. L. Zhang, R. Tanaka, T. Ohno, and K. Shimomura, "Identification of novel poly-acylated anthocyanins from gynura bicolor leaves and their antioxidative activity," Food Science and Technology Research, vol. 16, no. 5, pp. 479-486, 2010.

[16] L. Jiang, R. Y. Kang, L. Zhang, J. Jiang, and Z. F. Yu, “Differential protein profiles of postharvest Gynura bicolor D.C leaf treated by 1-methylcyclopropene and ethephon," Food Chemistry, vol. 176, pp. 27-39, 2015.

[17] L. Cui, Q. Huang, B. Yan et al., "Molecular cloning and expression analysis of a $\mathrm{Cu} / \mathrm{Zn}$ SOD gene (BcCSD1) from Brassica campestris ssp. chinensis," Food Chemistry, vol. 186, pp. 306-311, 2015.

[18] L. Jiang, Effects of Different Treatments on Postharvest Quality, Biochem-Physiology of Gynura D.C and POD Characteristics, Nanjing Agricultural University, Nanjing, China, 2010.

[19] F. Xu, Study on Effect and Mechanism of Postharvset Treatmebts on Delaying Senescence of Broccoli Florets, Nanjing Agricultural University, Nanjing, China, 2012.

[20] L. Wang, Study on the Change of Postharvest Physiology and Influencing Factor of Ficus carica L., Hebei Agricultural University, Baoding, China, 2012.

[21] T. Ma, Physiology and Quality Characteristics of Kiwifruit Affected by CPPU and 1-MCP Treatments, Northwest A\&F University, Yangling, China, 2015.

[22] H. R. Chen, L. Shen, L. Z. Ouyang et al., "Effects of nitric oxide (NO) on postharvest rape quality and reactive oxygen specious (ROS) metabolism related enzymes," Food Science, vol. 28, no. 7, pp. 493-496, 2007.

[23] B. Wu, Q. Guo, Q. Li, Y. Ha, X. Li, and W. Chen, "Impact of postharvest nitric oxide treatment on antioxidant enzymes and related genes in banana fruit in response to chilling tolerance," Postharvest Biology and Technology, vol. 92, pp. 157-163, 2014.

[24] C. Meiling, Effects and Mechanism of Hypobaric Treatment on Freshing-Keep of Blueberry and Broccoli, Ginling College, Nanjing, China, 2015. 
[25] R. Z. Guo, Y. Bai, W. L. Guo, and X. H. Kou, "Effect of hypobaric storage on antioxidant contents and antioxidant enzymes in tomato fruit," Science and Technology of Food Industry, vol. 34, no. 8, pp. 338-341, 2013.

[26] B. B. Nian, P. Li, and Y. Y. Guo, "Effect of $\mathrm{O}_{2} / \mathrm{CO}_{2}$ controlled atmospheres on active oxygen metabolism and storage quality of ginger," Northern Horticulture, no. 8, pp. 130-133, 2015.

[27] Y. Y. Guo, L. Li, D. Chen, Y. Y. Wang, and F. Pang, "Effects of $\mathrm{O}_{2}$ combined with $\mathrm{CO}_{2}$ controlled atmospheres on reactive oxygen species metabolism and quality preservation of broccoli (Brassica oleracea L.)," Food Science, vol. 34, no. 24, pp. 304-308, 2013.

[28] Y. J. Zhou, H. Y. Gao, H. J. Chen, F. Tao, and X. J. Fang, "Effects of hypobaric storage on reactive oxygen species metabolism of Pleurotus eryngii during cold storage," Journal of Nuclear Agricultural Sciences, vol. 29, no. 6, pp. 1108-1113, 2015. 

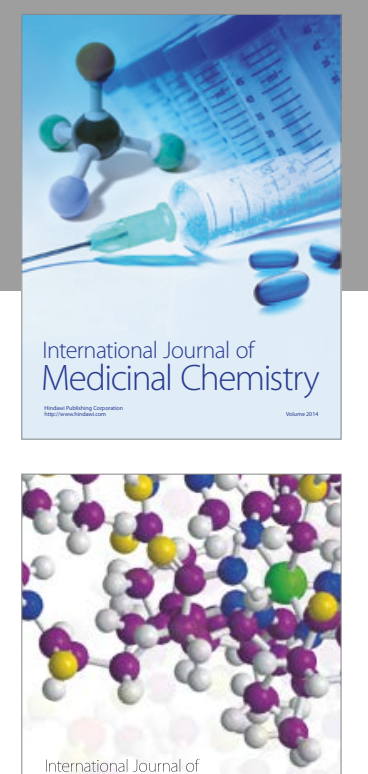

Carbohydrate Chemistry

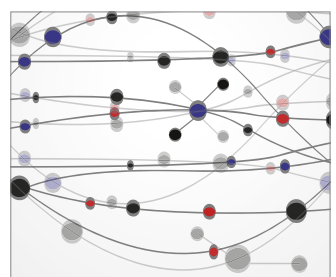

The Scientific World Journal
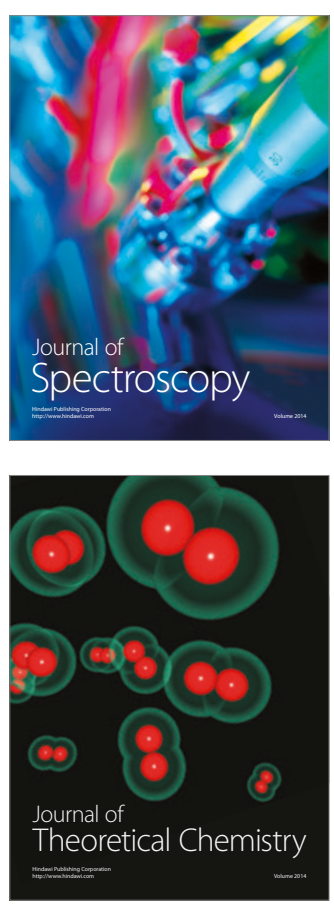
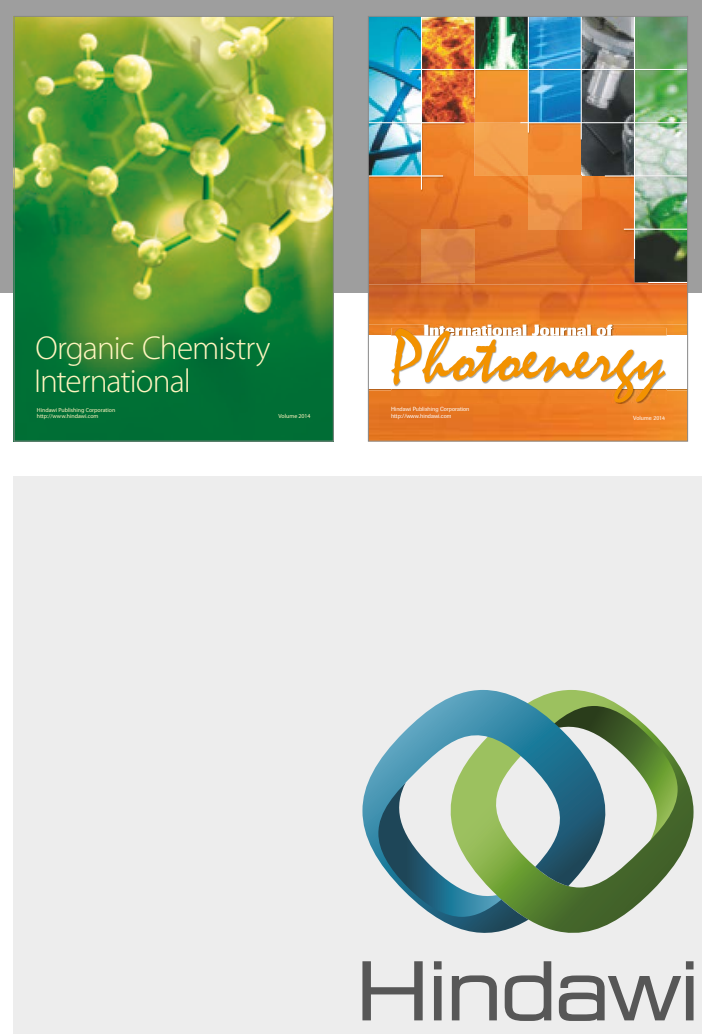

Submit your manuscripts at

https://www.hindawi.com

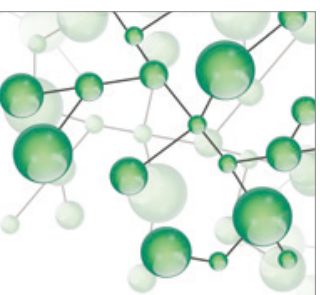

International Journal of

Inorganic Chemistry

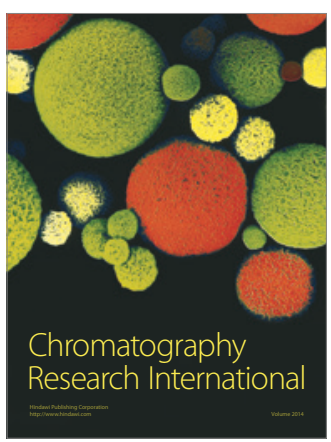

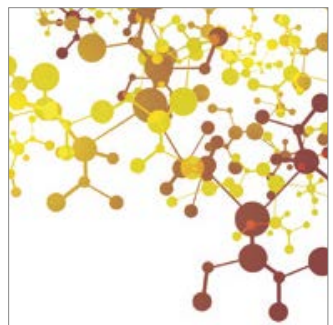

Applied Chemistry
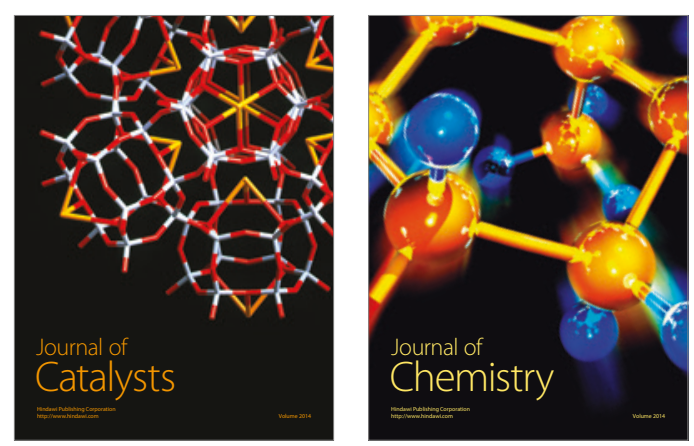
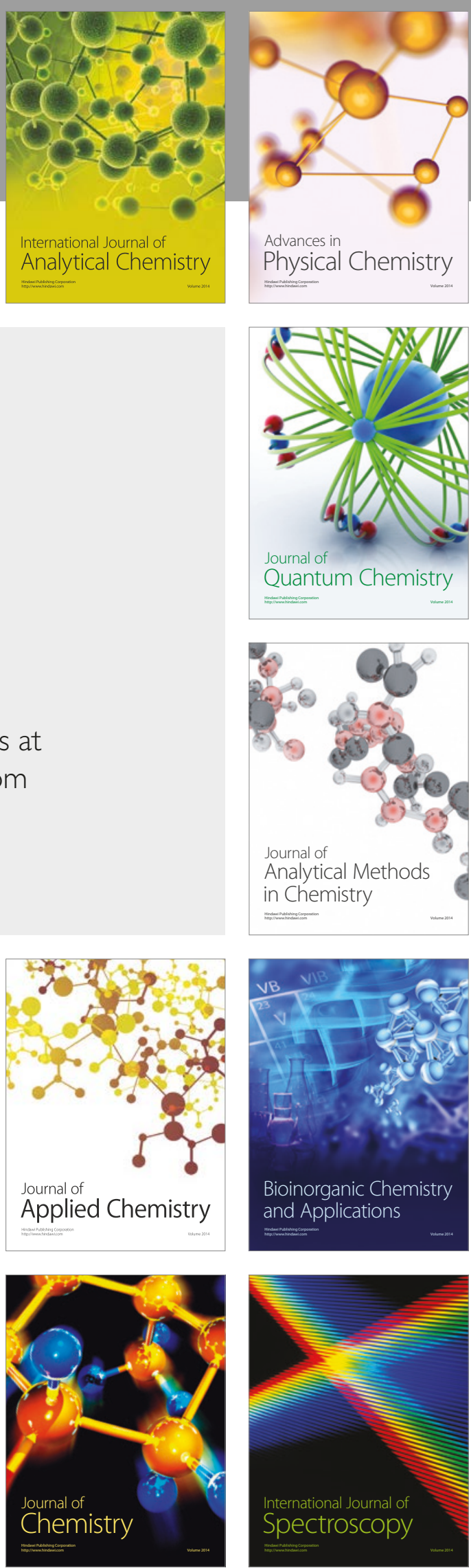